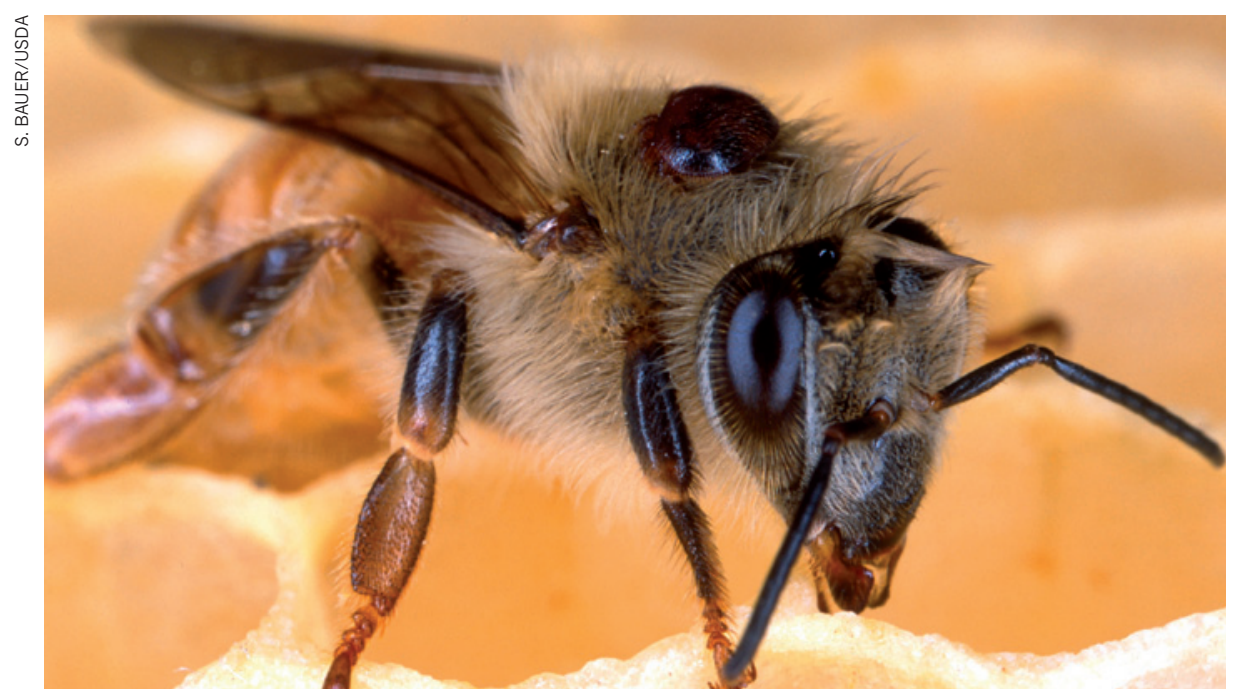

The honeybee is under threat from a formidable array of pathogens, including the Varroa mite seen here.

APIOLOGY

\title{
Geneticists bid to build a better bee
}

\section{Honeybee genome offers clues for fighting diseases.}

\section{BY GWYNETH DICKEY ZAKAIB}

$\mathrm{F}$ or Scott Cornman, the honeybee genome is a prized resource, yet he spends much of his time removing it. Cornman, a geneticist for the Bee Research Laboratory of the US Department of Agriculture (USDA) in Beltsville, Maryland, is trying to characterize the various pathogens that plague the honeybee (Apis mellifera), arguably the world's most important insect. His strategy is to subtract the honeybee genome from every other stray bit of genetic residue he can find in bee colonies, healthy and diseased. The remaining genetic material gives a complex metagenomic portrait of other organisms that inhabit the bee's world, including viruses, bacteria and fungi - some novel - that, alone or in combination, might push a bee colony into precipitous decline.

"Right now we're in the discovery phase, where we're trying to identify what's present," says Cornman. "Then we can start looking at the interactions of pathogens and see if they're more virulent than any by themselves."

Cornman was among 100 or so researchers in attendance last week at the Honey Bee Genomics \& Biology meeting, held at Cold Spring Harbor Laboratory in New York. It was the first dedicated conference on the topic since researchers met four years ago, soon after the honeybee genome was sequenced (Honeybee Genome Sequencing Consortium Nature 443, 931-949; 2006), and for many it was a chance to marvel at a field transformed.

"There has been a lot of progress made on how disease affects honeybees at the molecular level," says Christina Grozinger, director of Pennsylvania State University's Center for Pollinator Research in University Park, one of the conference organizers. Around the same time that the genome was first published, honeybee colonies across much of the Northern
Hemisphere began to show alarming declines. A syndrome dubbed colony collapse disorder (CCD) has been causing the insects to die off in large numbers, leaving well-provisioned hives suddenly empty. Meanwhile, other parasites, such as the Varroa mite (Varroa destructor), which spreads harmful viruses, continue to take their toll. Annual surveys in the United States show that almost $35 \%$ of all colonies die during a typical winter. Genomics is yielding new clues to the still-mysterious phenomenon, as well as potential strategies for protecting the insects from a multitude of threats.

At the meeting, Cornman presented data showing that hives affected by CCD have higher levels of microscopic gut fungi called Nosema, and a greater prevalence of several viruses, two of which had not been detected in bees before.

Yet despite having a multitude of enemies, many bees are holding their own, says research entomologist Jay Evans of the USDA's bee laboratory. "The question is not why are bees getting sick, but how are they surviving against this onslaught of parasites," he says.

The genome offers a window into the bees' immune pathways, Evans adds. The goal is to identify the genes that are crucial in helping bees thwart attack, and, ultimately, to strengthen these defences. "You can breed for these traits, but with genetic markers you could do it faster," he says.

In cases in which nature cannot do the job, some researchers are now exploring more direct ways of boosting bees' resilience. In some insects, double-stranded RNA, a hallmark of viral infection, can provoke a specific antiviral immune response. At the meeting, Michelle Flenniken, a virologist at the University of California, San Francisco, presented evidence that, in honeybees, it can also trigger a general immune response that might ward off a variety of threats. "This may be a new viral response that hasn't been well-characterized in honeybees," says Flenniken, who is exploring the genes involved in the process. "What we think we've found is a window into this new immune-response pathway."

Flenniken adds that knowing more about the bee's immune responses might help researchers to find ways of "priming the system" and help bees to cope with their foes at the genomic level. Such a prospect may be a long way off, but it's certain to keep researchers abuzz until their next gathering.

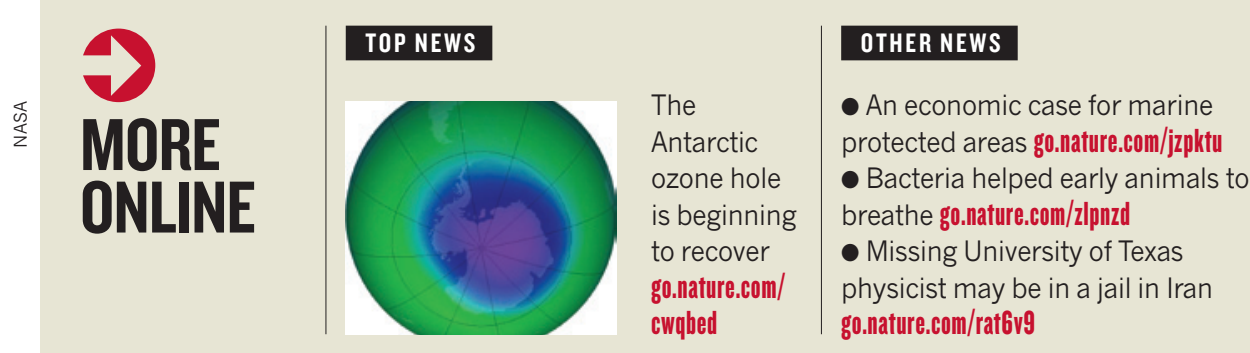

\begin{tabular}{l} 
EXPLAINER \\
$\begin{array}{l}\text { Why the } \\
\text { Mississippi } \\
\text { floods should } \\
\text { have been } \\
\text { expected } \\
\text { go.nature.com/ } \\
\text { srlzjc }\end{array}$ \\
\hline
\end{tabular}

